tion of the type itself". A. Weber has a short paper on the nerve fibres of the chick after spinal cord injuries to the embryo; and the geometrical characteristics of the head flexures, etc., of the chick embryo are described by E. Bujard. A very interesting paper is that by A. Portmann, who discusses the evolution of the mammalian placenta, concluding that although the histological classification of Grosser has much physiological importance, it cannot serve as the basis for an evolutionary scheme. A new scheme is provided. There is also an interesting schematization of the formation of the amnion in Eutheria by R. A. Goetz, who describes his work on the early development of the Tenrecoidea.

\section{Towns and Industry}

ONE of the great merits of the broadsheets issued by P E P (Political and Economic Planning) is the way in which they direct attention to neglected problems or to changing conditions which are creating new problems. A recent broadsheet on towns and industry is intended to stimulate discussion regarding the town as a background of industry, and as a social organism the development of which can be and is being shaped. Its analysis of the different types of town from the village and country town, through the traffic town, the port, the mining camp town, such as Corby, Kinlochleven and Fort William, the military town, the cathedral city, the school and university town, the resort, the residential town, the dormitory town, the planned town to the metropolitan centres, and particularly its bearing on transport questions, indicates very clearly how imperative is decision whether to accept the types of town resulting from the blind play of economic and social decisions, all taken regardless of the type of town they will develop, or whether to examine the different possible types of town, to agree on the merits and demerits of each, and to make economic and social decisions within a framework which will ensure that the towns of the future combine the maximum advantages and the minimum drawbacks of their various types. In the words of the broadsheet, our towns are, with few exceptions, deformed and diseased organisms. It is clear that no less than in the sphere of physical fitness, the conquest and eradication of disease depend on dispassionate scientific investigation.

\section{Technical Information and Research}

A PAPER by Dr. E. S. Hedges and Dr. C. E. Homer on "The Role of Technical Information in Industrial Research and Development", presented at the World Congress on Universal Documentation in Paris last year, has been included as No. 6 in the Miscellaneous Publications of the International Tin Research and Development Council. The paper reviews the functions of an information department in industrial research and development and describes the methods of disseminating technical information, with particular reference to those used for the collection, storing and distribution of information by the International Tin Research and Development Council. The policy of the Council of making available to those interested all information obtained is carried out to some extent by replies to inquiries but more generally by publishing all suitable informa. tion in the Technical Papers or Bulletins of the Council. The first are issued in several series. Series $A$ is devoted to accounts of original work carried out by the Council's investigators and usually consists of reprints of papers presented to scientific societies ; Series B consists of comprehensive accounts of special subjects; Series $\mathrm{C}$ is reserved for reports of new applications of tin; and Series D contains reports of original research by other organizations. The Miscellaneous Publications deal with general nontechnical topics of interest to the tin industry, while the Bulletins, which are written in a less severely technical style, endeavour to provide a survey of the tin-consuming industries.

\section{Study of Hormones}

WE have received "A Symposium on Hormones", being the Sigma Xi Lectures for 1936-37 in the Ohio State University (Ohio J. Sci., 37, No. 6, 315-463 ; 1937). These lectures are delivered biennially and the present volume is the third of the series. Owing to the size of the field, only certain aspects of each subject have been selected by the different authors for elucidation: and no discussion of the hormones of the parathyroids, thymus or pineal gland has been possible. The lectures include, however, two devoted to the growing field of the plant hormones, as well as discussions on the relationship of internal secretion to the nervous system by Leon Asher, and the less well-known hormones of the gastro-intestinal tract by A. C. Ivy. C. H. Best gives an interesting account of the prolongation of the action of insulin by addition of protamine and zinc. The sex hormones are dealt with by W. O. Nelson and $H$. O. Haterius, the thyroid hormone by D. Marine, the hormones of the adrenal gland by F. A. Hartman and those of the anterior lobe of the pituitary gland by $O$. Riddle. In each case the author has himself done much by experiment to advance our knowledge of the subject with which he deals.

\section{Raising the Compulsory School Attendance Age}

Local Education Authorities were advised by the Board of Education's circular 1457 as to preparations for meeting the situations arising when under the Education Act of 1936 applications are made for exemption from the obligation to continue attendance at school after the age of fourteen years. The preparations recommended comprise : a survey, with the help of juvenile employment committees and inspectors of factories, of the conditions and circumstances in which children generally between fourteen and fifteen years of age are at present employed; the prescription of forms for application for exemption, school reports and medical reports; the adoption of procedures already tested and found useful in regard to vocational advice; and co-operation between authorities for contiguous areas. The National Union of Teachers has issued a sixteen-page pamphlet commenting on the circular and making a number of other suggestions and re-affirming the Union's opinion that there should be no exemptions. 